\title{
THIACALIX[4]ARENE PHOSPHONATE C-800 AS A NOVEL FLUORESCENT PROBE FOR ZINC IN LIVING CELLS
}

\author{
V. I. YAVOROVSKA ${ }^{1}$, R. D. LABYNTSEVA ${ }^{1 凶}$, O. V. BEVZA ${ }^{1}$, A. Y. PUGACH ${ }^{1}$, \\ A. B. DRAPAILO ${ }^{2}$, S. O. CHERENOK ${ }^{2}$, V. I. KALCHENKO', S. O. KOSTERIN ${ }^{1}$ \\ ${ }^{1}$ Palladin Institute of Biochemistry, National Academy of Sciences of Ukraine, Kyiv; \\ ${ }^{2}$ Institute of Organic Chemistry, National Academy of Sciences of Ukraine, Kyiv; \\ e-mail: raisa.lab@gmail.com
}

Received: 07 April 2021; Accepted: 07 July 2021

Zn ions are significant for maintaining the proper human organism functioning, thus monitoring the zinc content in living cells and the development of sensitive tracking systems and sensors for Zn is particularly important. The purpose of the work was to study the properties of synthetic thiacalix[4]arene C-800 (5,11,17,23-tetrakis[(hydroxy-ethoxyphosphonyl)methyl])-25,26,27,28-tetrahydroxythiacalix[4]arene) as a fluorescent sensor for zinc ions in living cells. Our studies demonstrated that thiacalix[4]arene C-800 containing four hydroxy-ethoxyphosphonylmethyl groups on the upper rim exhibited fluorescent properties at $340 \mathrm{~nm}$ excitation wavelength. Fluorescence intensity of thiacalix[4]arene C-800 was increased significantly in the presence of $\mathrm{Zn}$ cations, while cations of other metals, such as $\mathrm{Mg}^{2+}, \mathrm{Ca}^{2+}, \mathrm{Cd}^{2+}$, and $\mathrm{Pb}^{2+}$ did not affect it. Computer modeling demonstrated that two Zn cations interact with the oxygen atoms of four hydroxy-ethoxyphosphonylmethyl groups. It was shown that thiacalix[4]arene C-800 quickly penetrated rat myometrial cells that led to an increased intracellular fluorescence level. The addition of $\mathrm{Zn}^{2+}$ to cells, stained with thiacalix[4]arene C-800, was followed an even greater increase of intracellular fluorescent signal intensity. No effect of thiacalix[4]arene C-800 on reactive oxygen species production in myometrial cells was detected as well as on cells viability in the range of its 50-250 $\mu \mathrm{M}$ concentrations. Thus, thiacalix[4]arene C-800 can potentially be used as a selective fluorescent probe for the detection of $\mathrm{Zn}^{2+}$ in living cells.

Ke ywords: myometrial cells, Zn ${ }^{2+}$, thiacalix[4]arene, fluorescent probe, molecular dynamic, MTT assay.

$\mathrm{U}$ p to $10 \%$ of the proteins, encoded by the human genome, contain putative $\mathrm{Zn}^{2+}$ binding motifs [1, 2], which suggests the significance of $\mathrm{Zn}^{2+}$ in biological systems. Its ions form complexes with multiple proteins, enzymes, metabolites, and other low molecular weight ligands that carry out vital metabolic functions [3]. Zincdependent proteins can be found in the cytoplasm and within many organelles of the eukaryotic cell including the nucleus, the endoplasmic reticulum, Golgi apparatus, secretory vesicles, and mitochondria. Cells possess zinc transport mechanisms, which allow them to accumulate and distribute metal ions $[4,5]$.
Various studies prove, that zinc deficiency can lead to serious diseases, such as mental retardation, Parkinson's disease, epilepsy, and certain types of cancer $[5,6]$. On the other hand, excessive doses of zinc are noxious for living organisms as well. It has been concluded that high concentrations of zinc intake can alter the immune response [7], cause several health problems, such as superficial skin diseases, diabetes, and brain disorders [8], and lead to the development and progression of Alzheimer's disease [9]. Moreover, excessive zinc intake can cause impairments and disorders of male and female reproductive systems $[10,11]$.

(C) 2021 Yavorovska V. I. et al. This is an open-access article distributed under the terms of the Creative Commons Attribution License, which permits unrestricted use, distribution, and reproduction in any medium, provided the original author and source are credited. 
Therefore, quantitative measurement of $\mathrm{Zn}^{2+}$ levels is important for monitoring biological and probable pathological processes in living organisms. In recent decades, many probes, including fluorescence probes, for zinc detection in living cells have been described in the scientific literature [12-17].

Fluorescence spectroscopy has several advantages over other methods due to its high sensitivity, easy visualization, and short response time. Therefore, it was important to find a probe for $\mathrm{Zn}^{2+}$ that would be fluorescent, easily penetrating through the plasma membrane into living cells, and, at the same time would be safe for the cells. The cup-shaped three-dimensional calix[4]arene platforms are widely used as building blocks for the creation of $\mathrm{Zn}^{2+}$ selective fluorescent sensors [18]. However, to the best of our knowledge, bigger in size thiacalix[4]arenes possessing four sulfur atoms inside macrocyclic platform were never used for this aim. It is well known that the sulfur atoms together with oxygen atoms at the lower rim can form five-membered chelate type complexes with zinc and other transitional metals $[19,20]$. Our attention was drawn to the thiacalix[4]arene phosphonous acids, with which we have been working for many years and obtained interesting results on their ability to eliminate the inhibitory effect of heavy metals, including $\mathrm{Zn}^{2+}$ on the activity of myometrial myosin ATPase [21].

The work aimed to study the properties of thiacalix[4]arene methylphosphonic acid C-799 and its tetraethyl ester C-800 as a fluorescent sensor for zinc ions, which would easily penetrate living cells and would be safe for them. Rat myometrial cells were used as a model.

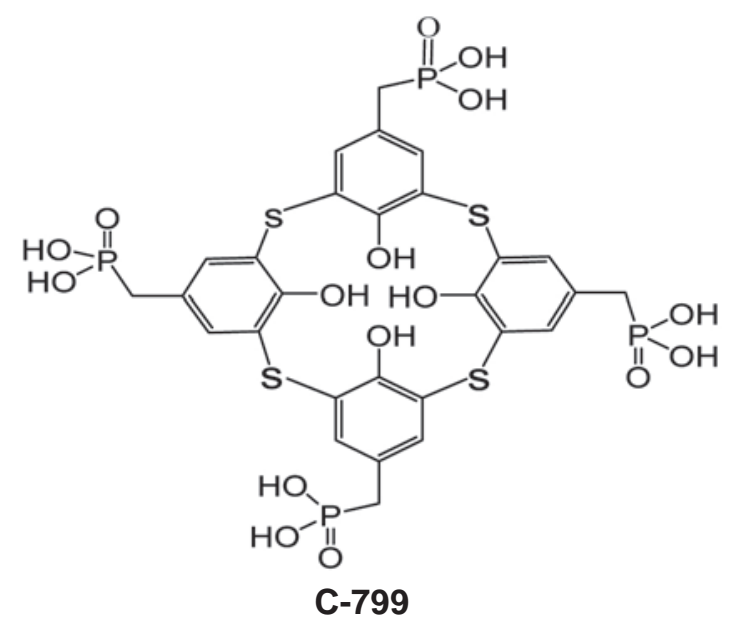

\section{Materials and Methods}

Thiacalixarenes C-799 and C-800 (Fig. 1) were synthesized using the early described methods [22, 23].

All chemicals used in the experiments were provided by Sigma Aldrich. All the solutions were prepared using distilled water, obtained in Crystal Bio (Adrona, Latvia). The water conductance was $0.055 \mu \mathrm{S} / \mathrm{cm}$. The concentration of the divalent metal cations in solutions was determined by the Mohr method. Fluorescence spectra were recorded using the Qanta Master PTI 40 spectrofluorimeter (Photon Technology International). The thiacalix[4]arene fluorescence in cells was studied using a Confocal microscope Carl Zeiss LSM 510 Meta (Carl Zeiss, Germany).

Fluorescent spectroscopy. The stock aqueous solutions (water conductance $-0.055 \mu \mathrm{S} / \mathrm{cm}$ ) of thiacalix[4]arenes C-799 and C-800 (1 mM) were prepared and alkalinized with $\mathrm{NaOH}$ until completion of a dissolution. The fluorescence spectra of the thiacalix[4]arenes $(5-100 \mu \mathrm{M})$ solutions separately and in the presence of metal cations $(0.5-5 \mathrm{mM})$ were determined using the Qanta Master PTI 40 and FelixGX 4.1.0.3096 software. The excitation wavelength was $340 \mathrm{~nm}$, the emission range was 350$480 \mathrm{~nm}$.

The isolation of uterine smooth muscle cells. All animal manipulations were carried out in accordance with the European Convention for the protection of vertebrate animals used for experimental and other scientific purposes (Strasbourg, 1986).

Myocyte suspension of the nonpregnant rat uterus was obtained using collagenase type $1 \mathrm{~A}$

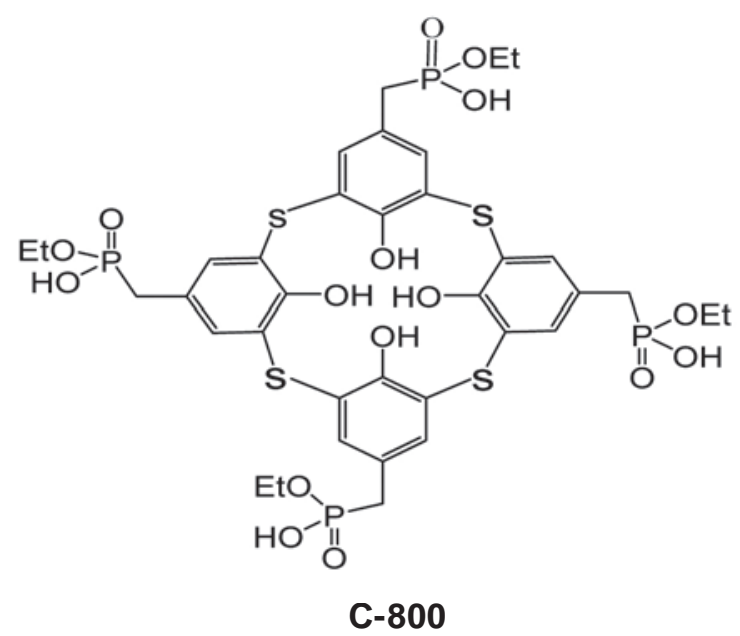

Fig. 1. The structural formulas of the thiacalixarenes C-799 and C-800 
and soybean trypsin inhibitor by modified Gangula method [24]. The rats were kept in a stationary vivarium at constant temperature and baseline. The animals were anesthetized with chloroform and then sacrificed by cervical dislocation. The uterus of adult rats was rapidly harvested and dissected into $1 \mathrm{~mm}^{3}$ pieces in Hanks balanced salt solution $(136.9 \mathrm{mM}$ $\mathrm{NaCl}, 5.36 \mathrm{mM} \mathrm{KCl}, 0.44 \mathrm{mM} \mathrm{KH}_{2} \mathrm{PO}_{4}, 0.26 \mathrm{mM}$ $\mathrm{Na}_{2} \mathrm{HPO}_{4}, 4.5 \mathrm{mM} \mathrm{NaHCO}, 0.03 \mathrm{mM} \mathrm{MgCl}$, $5 \mathrm{mM}$ glucose, $10 \mathrm{mM}$ HEPES, $\mathrm{pH} 7.4$ at $37^{\circ} \mathrm{C}$ ) with $1.26 \mathrm{mM} \mathrm{Ca}^{2+}$ and $0.8 \mathrm{mM} \mathrm{Mg}^{2+}$. The pieces were then washed with Hanks solution (without $1.26 \mathrm{mM}$ $\mathrm{Ca}^{2+}$ and $0.8 \mathrm{mM} \mathrm{Mg}^{2+}$ added) 3 times to dispose of the blood and debris. The uterine pieces were placed into a digestion buffer containing $0.1 \%$ collagenase type IA and $0.01 \%$ soybean trypsin inhibitor and digested at $37^{\circ} \mathrm{C}$ in a water-bath with continuous shaking for $20 \mathrm{~min}$. The digestion buffer was then discarded, and Hanks solution without $\mathrm{Ca}^{2+}$ and $\mathrm{Mg}^{2+}$ was added and pipetted for $5 \mathrm{~min}$. The last two steps were repeated 4 times. The first portion of Hanks solution without $\mathrm{Ca}^{2+}$ and $\mathrm{Mg}^{2+}$ after pipetting was also discarded while subsequent portions of Hanks solution (without $\mathrm{Ca}^{2+}$ and $\mathrm{Mg}^{2+}$ ), that contain the cells were collected. Cells were then precipitated by centrifugation at $500 \mathrm{~g}$ for $10 \mathrm{~min}$ and diluted in PBS (phosphate-buffered saline: $0.8 \% \mathrm{NaCl}, 0.02 \% \mathrm{KCl}$, $0.144 \% \mathrm{Na}_{2} \mathrm{HPO}_{4}, 0.024 \% \mathrm{KH}_{2} \mathrm{PO} 4, \mathrm{pH} 7.4$ ), to a final concentration of 5-8 $\times 10^{6}$ cells $/ \mathrm{ml}$.

The primary myocyte cell culture. All procedures for obtaining cultivated myocytes were performed in sterile conditions under a laminar flow using collagenase type $1 \mathrm{~A}$. The cells were cultivated in RPMI-1640 or DMEM F-12 nutrient medium with a mix of antibiotics (penicillin $1000 \mathrm{U} / \mathrm{ml}$, streptomycin $100 \mu \mathrm{g} / \mathrm{ml}$ ) and an antimycotic (amphotericin B $0.25 \mu \mathrm{g} / \mathrm{ml}$ ), and $20 \%$ fetal bovine serum at $37^{\circ} \mathrm{C}$ at $5 \% \mathrm{CO}_{2}$ concentration in the atmosphere (standard conditions).

The MTT proliferative assay. Cells were grown to a confluent state on 96-well plates to perform MTT proliferative assay. The cells were washed with PBS before adding thiacalix[4]arene C-800. The medium was replaced on a serum-free one with a concentration of 50 to $500 \mu \mathrm{M}$ calix[4]arene. Then, the cells were cultivated for $24 \mathrm{~h}$ in standard conditions. The control cells were incubated in the analogous conditions in PBS without adding thiacalix[4]arene C-800. Further, the content of the wells with cells was substituted by a new nutrient medium with $0.5 \mathrm{mg} / \mathrm{ml}$ solution of MTT reagent and incubated for $4 \mathrm{~h}$ at $37^{\circ} \mathrm{C}$, which led to the transformation of water-soluble MTT onto insoluble violet formazan crystals. Formazan was solubilized with the addition of $10 \%$ SDS and $0.6 \%$ acetic acid in DMSO for 5 min under intensive shaking [25]. Formazan concentration was determined by the solution optical absorption at $545 \mathrm{~nm}$ (assay) and $630 \mathrm{~nm}$ (comparison) on $\mu$ Quwant plate reader (Biotek Instruments, Inc., USA)

The study of the interaction between thiacalix[4]arene $\mathrm{C}-800$ and $\mathrm{Zn}^{2+}$ in living cells. The rat uterine cells suspension in PBS were placed on slides, preliminary coated with poly-L-lysine for $2 \mathrm{~h}$, and treated with $100 \mu \mathrm{M}$ thiacalix[4] arene and $5 \mathrm{mM}$ $\mathrm{Zn}^{2+}$. The fluorescence of thiacalix[4] arene C-800 in cells was studied using microscope Zeiss Axiovert 200M. Objective LD Plan- Neofluar 40×/0.6. Probes were illuminated with ultraviolet mercury lamp HBO-103 W/2 and analyzed under a blue filter (FSet01wf). The fluorescence images were registered using Zeiss AxioCam HRC digital camera. Image analysis was performed in FIJI software [26].

Detection of reactive oxygen species (ROS) in uterine cells in the presence thiacalix[4]arene C-800. The rat myometrial cell suspension was loaded with $50 \mu \mathrm{M} 2^{\prime}, 7^{\prime}$-dichlorodihydrofluorescein diacetate (DCF-DA) for $40 \mathrm{~min}$. at $37^{\circ} \mathrm{C}$ with constant stirring. The level of reactive oxygen species under the action of thiacalix[4]arene C-800 was recorded in a suspension of uterine myocytes after their $5 \mathrm{~min}$ incubation with $100 \mu \mathrm{M}$ thiacalix[4]arene C-800 in PBS. The ROS generation was investigated using a COULTER EPICS XL flow cytofluorimeter (Beckman Coulter, USA) with an argon laser (excitation with $488 \mathrm{~nm}$ ). The results of these experiments were analyzed using SYSTEM IITM Software (Beckman Coulter, USA).

Molecular modeling. Molecular modeling of thiacalixarene C-800 and its complexes with zinc cations were carried out using a HyperChem, version 8.0 program [27]. The structures were optimized by the semi-empirical PM3 method.

\section{Results and Discussion}

The study of the fluorescent properties of thiacalix[4]arene C-800. Thiacalix[4]arene C-800 consists of a cup, formed by four benzene rings, functionalized on the upper and the lower rim. The upper rim of thiacalix[4]arene C-800 contains four hydroxyethoxyphosphonylmethyl groups, and the lower rim contains four hydroxyl groups and diva- 
lent sulfur atoms (called bridging sulfur) [20]. In an aqueous solution, thiacalix[4]arene C-800 exhibits fluorescent properties at $340 \mathrm{~nm}$ excitation wavelength. The maximum emission for thiacalix[4]arene C-800 was observed at $380 \mathrm{~nm}$. Experimental data demonstrates, that the fluorescence intensity of thiacalix[4]arene C-800 increases with the addition of $\mathrm{Zn}^{2+}$ to the solution and dependent on $\mathrm{Zn}^{2+}$ concentration (0.1-5 mM). The thiacalix[4]arene C-800 fluorescence intensity at a constant concentration of thiacalix[4]arene C-800 $(100 \mu \mathrm{M})$ in the presence of $0.1 \mathrm{mM} \mathrm{Zn}^{2+}$ increases twice, in the presence of $0.25 \mathrm{mM} \mathrm{Zn}^{2+}$ - almost by 10 times, and in the presence 4 and $5 \mathrm{mM} \mathrm{Zn}^{2+}$ - by as much as 100 times (Fig. 2, A).

The observed ability of $\mathrm{Zn}^{2+}$ to increase the fluorescence of thiacalix[4]arene C-800 in an aqueous solution is the basis for the C-800 application as a potential sensor for $\mathrm{Zn}^{2+}$ in living cells. Obviously, the perfect sensor for $\mathrm{Zn}^{2+}$ must be both selective to $\mathrm{Zn}^{2+}$ and insensitive to other metals, present in the biological environment $[13,28]$. A comparative study of $\mathrm{Zn}^{2+}$ and other metal cations, including physiologic metals essential ones for humans, such as $\mathrm{Mg}^{2+}$ and $\mathrm{Ca}^{2+}$ as well as heavy metals $\left(\mathrm{Pb}^{2+}\right.$ and $\mathrm{Cd}^{2+}$ ) effect on the thiacalix[4]arene C-800 fluorescence intensity, it was shown that it was only increased upon the influence of $\mathrm{Zn}^{2+}$ (Fig. 2, B). The absence of the effect of other cations except for $\mathrm{Zn}^{2+}$ on thiacalix[4]arene C-800 fluorescence intensity can be partly explained by different ion radii of metal cations. In particular, $\mathrm{Cd}^{2+}, \mathrm{Pd}^{2+}$ and $\mathrm{Ca}^{2+}$ possess dissimilar radii comparing to $\mathrm{Zn}^{2+}$ [29]. Although, the radii of the cations are of great importance the radii of $\mathrm{Mg}^{2+}$ and $\mathrm{Zn}^{2+}$ are very close. Therefore, in this case, the features of the interaction of metal cations with donor atoms are more significant. Fig. 2,C has shown a comparative study of the $\mathrm{Zn}^{2+}$ effect on the fluorescence of the thiacalix[4]arene C-800 and its analog, the thiacalix[4]arene C-799. The latter thiacalix[4]arene, similarly to C-800, has four dihydroxyphosphonylmethyl groups. However, it does not contain the ethyl groups, present in the thiacalix[4]arene C-800. It was found that the thiacalix[4]arene C-799 fluorescence intensity also increased in the availability of $\mathrm{Zn}^{2+}$. However, the effect of $\mathrm{Zn}^{2+}$ on the thiacalix[4]arene C-799 fluorescence was inferior to its effect on thiacalix[4]arene C-800 fluorescence by 2.5 times.

Molecular modeling of structures of thiacalix[4]arene C-800 and its $\mathrm{Zn}^{2+}$ complexes. According to HyperChem program's calculations, the molecule of thiacalixarene C-800 has three main local minima of heat formation (structures A, B, C, Fig. 3). Among them, the most energetically profitable is the structure $\mathbf{C}$ with the conformation 1.3- alternate in which two pairs of distal benzene rings of the macrocyclic skeleton are oriented in opposite directions from the main plane of the macrocycle formed by four sulfur atoms. This structure is stabilized by four intramolecular hydrogen bonds $\mathrm{P}=\mathrm{O}$...H-O between phosphonic groups located on opposite sides of the macrocyclic skeleton. The other two structures $\mathbf{A}$ and $\mathbf{B}$ differ from structure $\mathbf{C}$ both in energy $(\Delta \Delta \mathrm{H}=-5 \mathrm{kcal} / \mathrm{mol}$ and $-16.1 \mathrm{kcal} / \mathrm{mol}$, respectively) and in the conformation of the macrocyclic skeleton. Structures A and $\mathbf{B}$ have flattened cone conformation in which two pairs of distal benzene rings are oriented "perpendicularly" and "coplanar" to the main plane of the macrocycle. Structure A is stabilized by two intramolecular hydrogen bonds $\mathrm{P}=\mathrm{O} \ldots$ $\mathrm{H}-\mathrm{O}$ between the distally located phosphonic groups. At the same time, structure $\mathbf{B}$ is stabilized by two pairs of such hydrogen bonds between proximal phosphonic groups. Structures $\mathbf{A}$ and $\mathbf{B}$ differ in the values of dihedral and valence angles in the macrocyclic skeleton and fragments P-C-C-C. Structure B is sterically more intense and less energetically profitable than $\mathbf{A}(\Delta \Delta \mathrm{H}=-11.1 \mathrm{kcal} / \mathrm{mol})$.

According to molecular modeling, thiacalixarene C-800 can chelate $\mathrm{Zn}$ cations by two phosphonic groups at the upper rim (structures $\mathbf{D}, \mathbf{E}, \mathbf{F}$ ) or chelate by two oxygen atoms and one sulfur atom at the lower rim of the macrocycle [29] (structure G). Complex $\mathbf{G}$ is more energetically profitable than isomeric complexes $\mathbf{E}(\Delta \Delta \mathrm{H}=-45.1 \mathrm{kcal} / \mathrm{mol})$ and $\mathbf{F}$ $(\Delta \Delta \mathrm{H}=-30.8 \mathrm{kcal} / \mathrm{mol})$.

The complexation changes the dihedral angles in the macrocyclic skeleton of thiacalixarene (Table). These changes depend on the conformation of the macrocycle and the zinc-binding mechanism. The 1.3-alternate conformation of ligand $\mathbf{C}$ is the most adapted for binding of the $\mathrm{Zn}$ cation by phosphonic groups, and changes in the dihedral angles during complexation are minimal. Significantly greater changes are observed for chelation of $\mathrm{Zn}^{2+}$ by distal and proximal phosphonic groups in cone-shaped structures $\mathbf{A}$ and $\mathbf{B}$. However, the most significant changes are observed for zinc-binding by the lower rim of the cone-shaped ligands $\mathbf{A}$ and $\mathbf{B}$. The flattened cone conformation of ligands $\mathbf{A}, \mathbf{B}$ during complexation is transformed into the regular cone conformation of complex $\mathbf{G}$. It should be noted that 
$A$

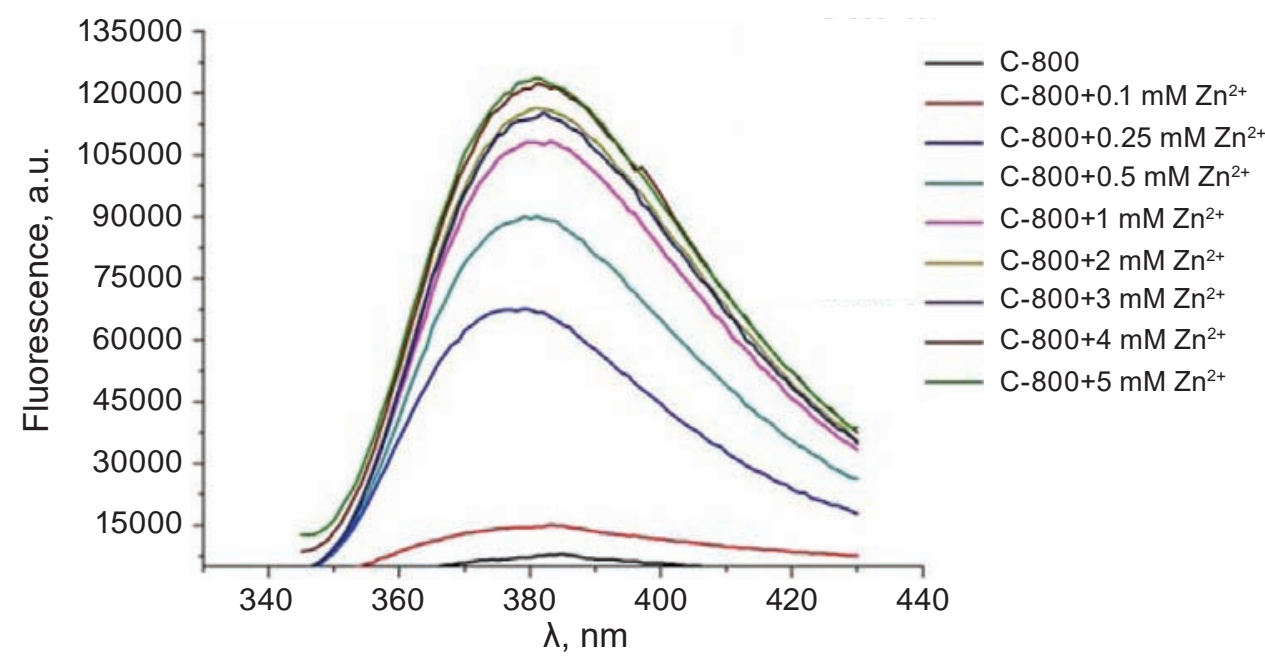

$B$

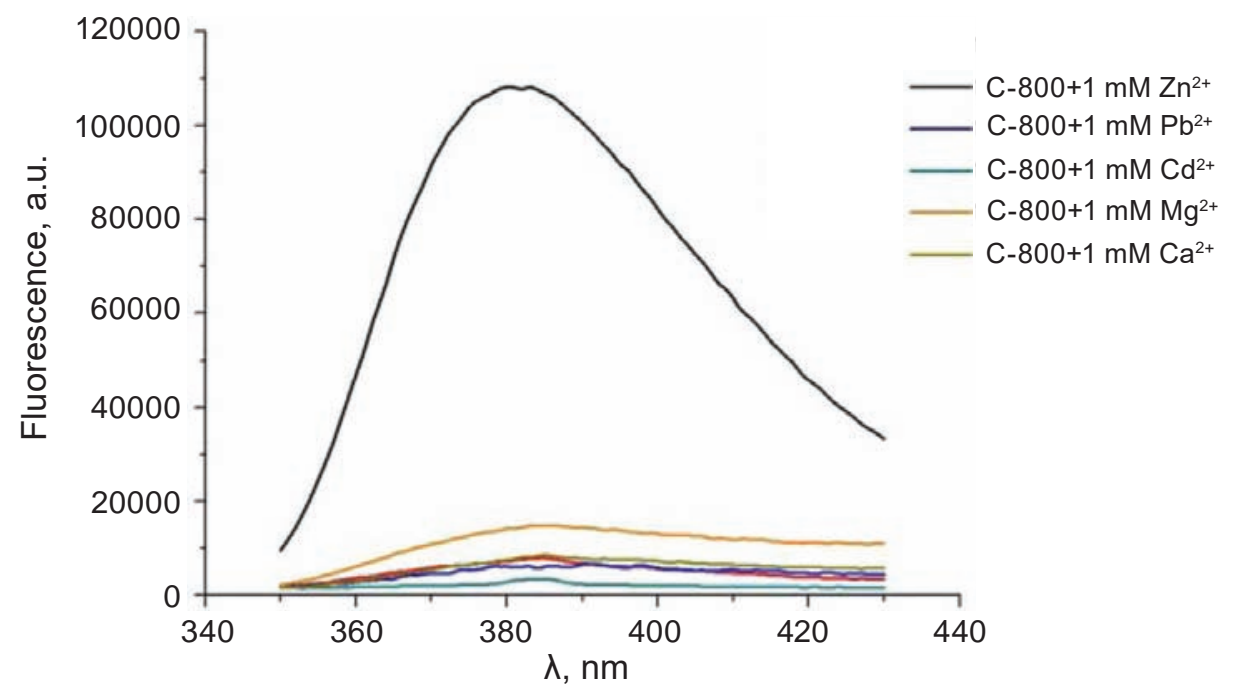

C

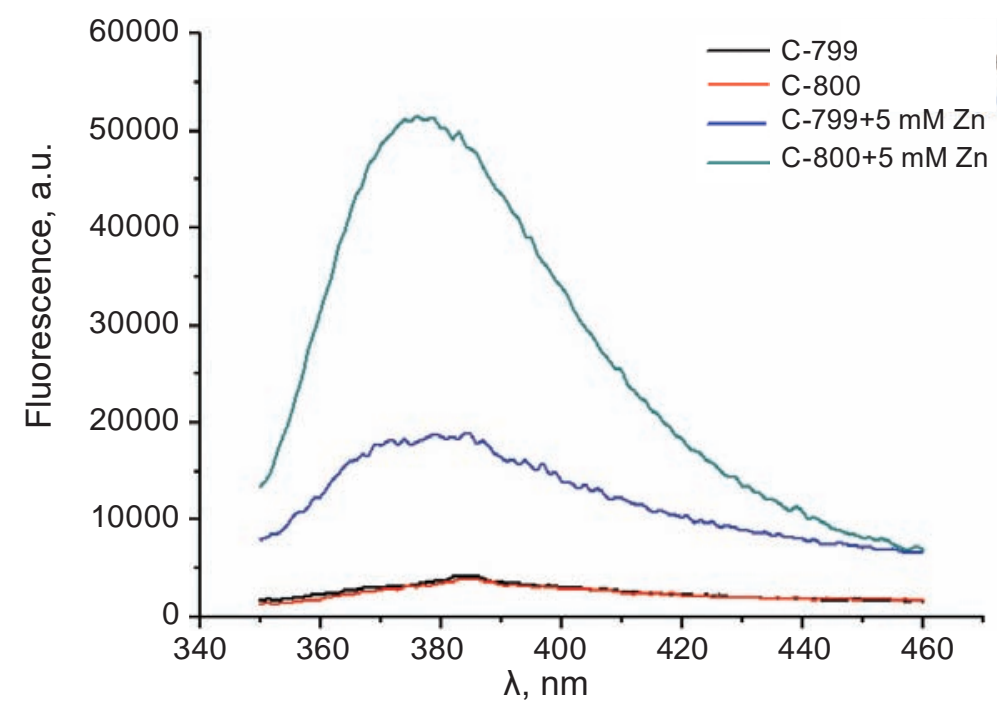

Fig. 2. Fluorescence spectra of thiacalix[4]arene C-800 in aqueous solution. $\boldsymbol{A}$ - dependence of the fluorescence intensity of thiacalix[4]arene $C-800$ on different $\mathrm{Zn}^{2+}$ concentrations. $\boldsymbol{B}$ - fluorescence spectra of $100 \mu \mathrm{M}$ thiacalix[4]arene $\mathrm{C}-800$ alone (control) and with various metal cations $\left(\mathrm{Zn}^{2+}, \mathrm{Pb}^{2+}, \mathrm{Cd}^{2+}, \mathrm{Mg}^{2+}\right.$ and $\left.\mathrm{Ca}^{2+}\right) . \mathrm{C}$-fluorescence spectra of thiacalix[4]arenes $\mathrm{C}-800$ and $\mathrm{C}-799$ with $5 \mathrm{mM} \mathrm{Zn^{2+ }}$ 


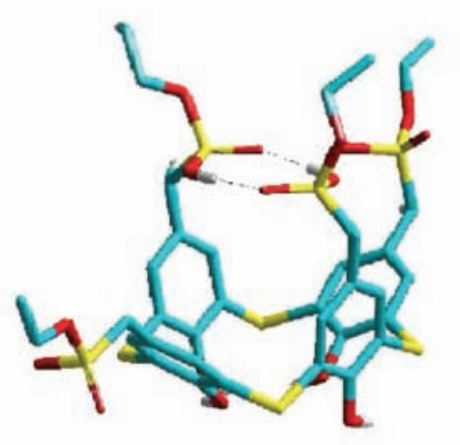

A

$\Delta \mathrm{H}=-794.5 \mathrm{kcal} / \mathrm{mol}$

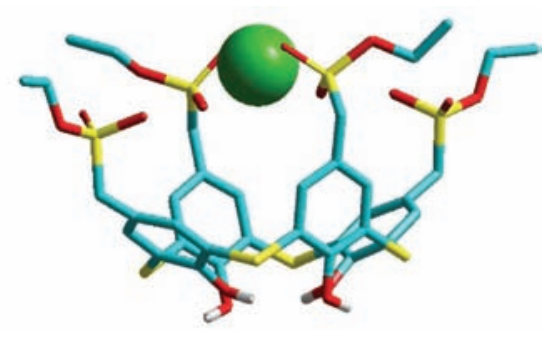

D

$\Delta \mathrm{H}=-716.1 \mathrm{kcal} / \mathrm{mol}$

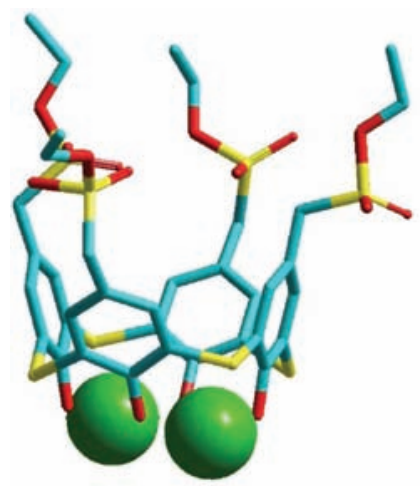

G (side view)

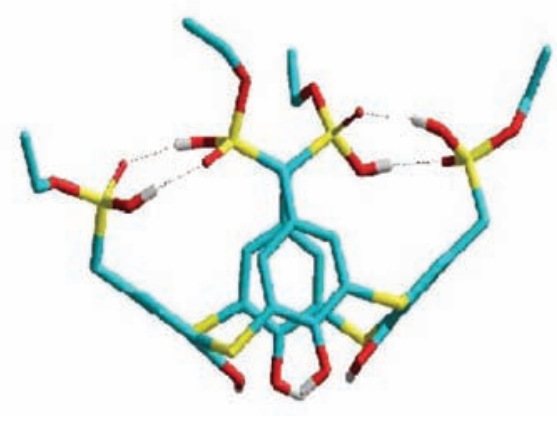

B

$\Delta \mathrm{H}=-783.4 \mathrm{kcal} / \mathrm{mol}$

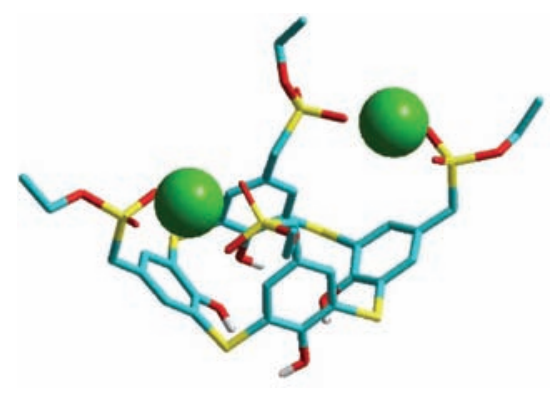

E

$\Delta \mathrm{H}=-619.3 \mathrm{kcal} / \mathrm{mol}$

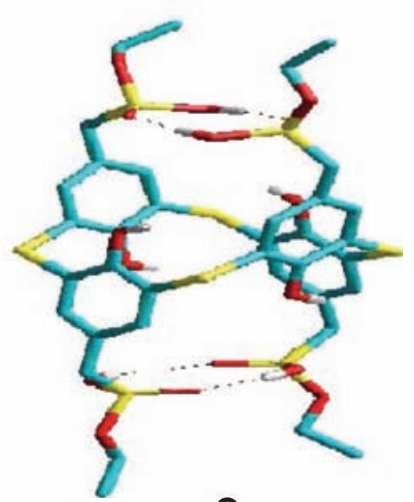

C

$\Delta \mathrm{H}=-799.5 \mathrm{kcal} / \mathrm{mol}$

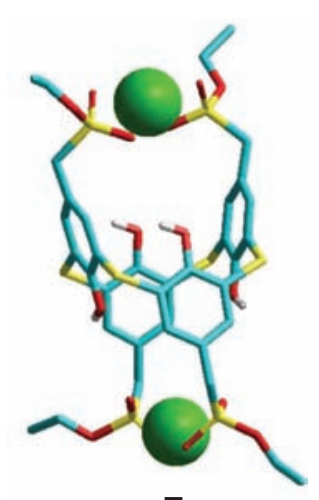

$\mathbf{F}$

$\Delta \mathrm{H}=-633.6 \mathrm{kcal} / \mathrm{mol}$

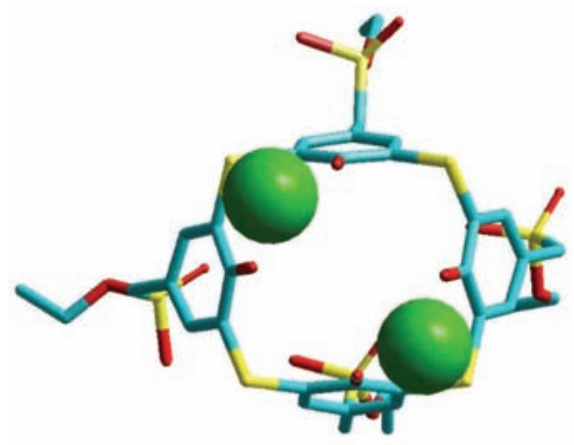

G (bottom view)

Fig. 3. Energy minimized structures of thiacalixarene $C-800(\boldsymbol{A}, \boldsymbol{B}, \boldsymbol{C})$ and its zinc complexes $(\boldsymbol{D}, \boldsymbol{E}, \boldsymbol{F}, \boldsymbol{G})$ (HyperChem, PM3)

in complex $\mathbf{G}$ the intramolecular hydrogen bonds $\mathrm{P}=\mathrm{O} \ldots \mathrm{H}-\mathrm{O}$ at the upper rim disappear as result of allosteric effect.

Such changes of the spatial structure may increase the fluorescence intensity of thiacalixarene $\mathrm{C}-800$ in the presence of $\mathrm{Zn}^{2+}$. The increase of fluo- rescence can also be induced by the interaction of the $\mathrm{Zn}^{2+}$ with the free electron pairs of oxygen and sulfur atoms that are part of the chromophore system of the thiacalixarene molecule.

The study of thiacalix[4]arene C-800 effect on the viability of uterine cells. It was necessary to de- 
Ta b l e. Dihedral angles $\left(^{\circ}\right)$ between benzene rings I, II, III, IV and the macrocycle's main plane in free ligands $\boldsymbol{A}, \boldsymbol{B}, \boldsymbol{C}$ and their zinc complexes $\boldsymbol{D}, \boldsymbol{E}, \boldsymbol{F}, \boldsymbol{G}$

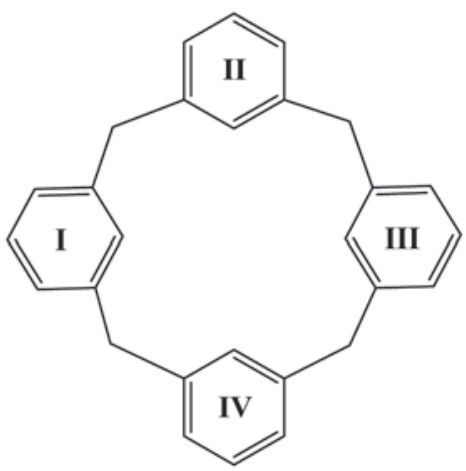

termine the cytotoxicity of thiacalix[4]arene C-800 on uterine myocytes for further experiments in the presence of such concentrations of thiacalix[4]arene C-800, which would not be toxic for cells. MTT assay was used to study the effect of thiacalix[4]arene C-800 on the viability of the uterine cells. It is based on the ability of mitochondrial dehydrogenases of actively respiring cells to convert water-soluble 3-(4,5-dimethylthiazol-2-yl)-2,5-diphenyltetrazolium bromide (MTT) into insoluble purple formazan, which is crystallized inside the cells. Formazan solubilization with the use of DMSO and further photometry allows us to detect exact changes in the solution absorption as compared to the control, which corresponds to the change in the number of viable cells and to estimate the cell death, induced by one or another cytotoxic agent [15]. It was determined (Fig. 4), using MTT assay, that thiacalix[4]arene C-800 added to the uterine cell culture in concentrations from 50 to $250 \mu \mathrm{M}$ did not affect the uterine cell viability. The death of almost $30 \%$ of cells was observed after further increasing of thiacalix[4]arene $\mathrm{C}-800$ concentration to $500 \mu \mathrm{M}$. Thus, we chose thiacalix[4]arene C-800 concentrations ranging from 50 to $250 \mu \mathrm{M}$ for further study.

Bioimaging of $\mathrm{Zn}^{2+}$ in a living cell by thiacalix[4]arene C-800 probe. The high sensitivity, selectivity, and low cell cytotoxicity of thiacalix[4]arene C-800 probe opens a door for the potential biological application of thiacalix[4] arene C-800 for fluorescence imaging to detect $\mathrm{Zn}^{2+}$ in living cells. The thiacalix[4]arene C-800 detection of $\mathrm{Zn}^{2+}$, and fluorescence imaging experiments were carried out in myometrial rat cell suspension. As shown in Fig. 5 $(B-D)$, incubation of uterine cells with $100 \mu \mathrm{M}$ thiacalix[4]arene C-800 at room temperature increases the fluorescence intensity of cells compared

\begin{tabular}{|c|c|c|c|c|}
\hline Structure & I & II & III & IV \\
\hline $\mathbf{A}$ & 141 & 106 & 137 & 95 \\
\hline $\mathbf{B}$ & 143 & 77 & 142 & 81 \\
\hline $\mathbf{C}$ & 100 & 101 & 100 & 102 \\
\hline $\mathbf{D}$ & 146 & 101 & 143 & 102 \\
\hline $\mathbf{E}$ & 134 & 91 & 127 & 102 \\
\hline $\mathbf{F}$ & 103 & 103 & 100 & 99 \\
\hline $\mathbf{G}$ & 122 & 99 & 125 & 103 \\
\hline
\end{tabular}

to control (Fig. 5, A). Moreover, incubation with $5 \mathrm{mM} \mathrm{ZnCl}$ of pre-stained with thiacalix[4]arene C-800 cells further enhances its fluorescence (Fig. 5, $E-G)$. In Fig. 6 shown the mean fluorescence intensity of cells incubated with thiacalix[4]arene C-800 and thiacalix[4]arene C-800 with $5 \mathrm{mM} \mathrm{ZnCl}_{2}$ compared to control that is shown in Fig. 6. Cells without the addition of thiacalix[4]arene C-800 and $\mathrm{Zn}^{2+}$ served as a control.

It can be concluded that thiacalix[4]arene C-800 can pass through the cell membrane and can be used for the detection of living cells.

Thus, thiacalix[4]arene C-800 not only exhibits $\mathrm{Zn}^{2+}$-dependent fluorescence in an aqueous solution but can also be used for targeted imaging of $\mathrm{Zn}^{2+}$ in the cells. However, the effect of $\mathrm{Zn}$ on thiacalix[4]arene C-800 fluorescence in cells appeared to be less pronounced than it was in an aqueous solu-

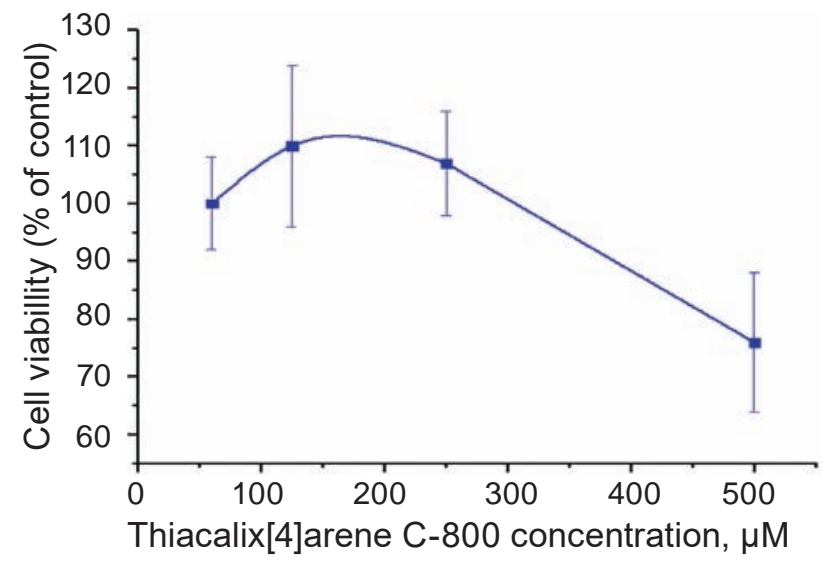

Fig. 4. Effect of thiacalix[4]arene C-800 on the viability of the uterine cells, observed during MTT assay $(M \pm S D, n=4)$. The value of formazan absorption in the absence of thiacalix[4]arene was taken as $100 \%$ (control) 

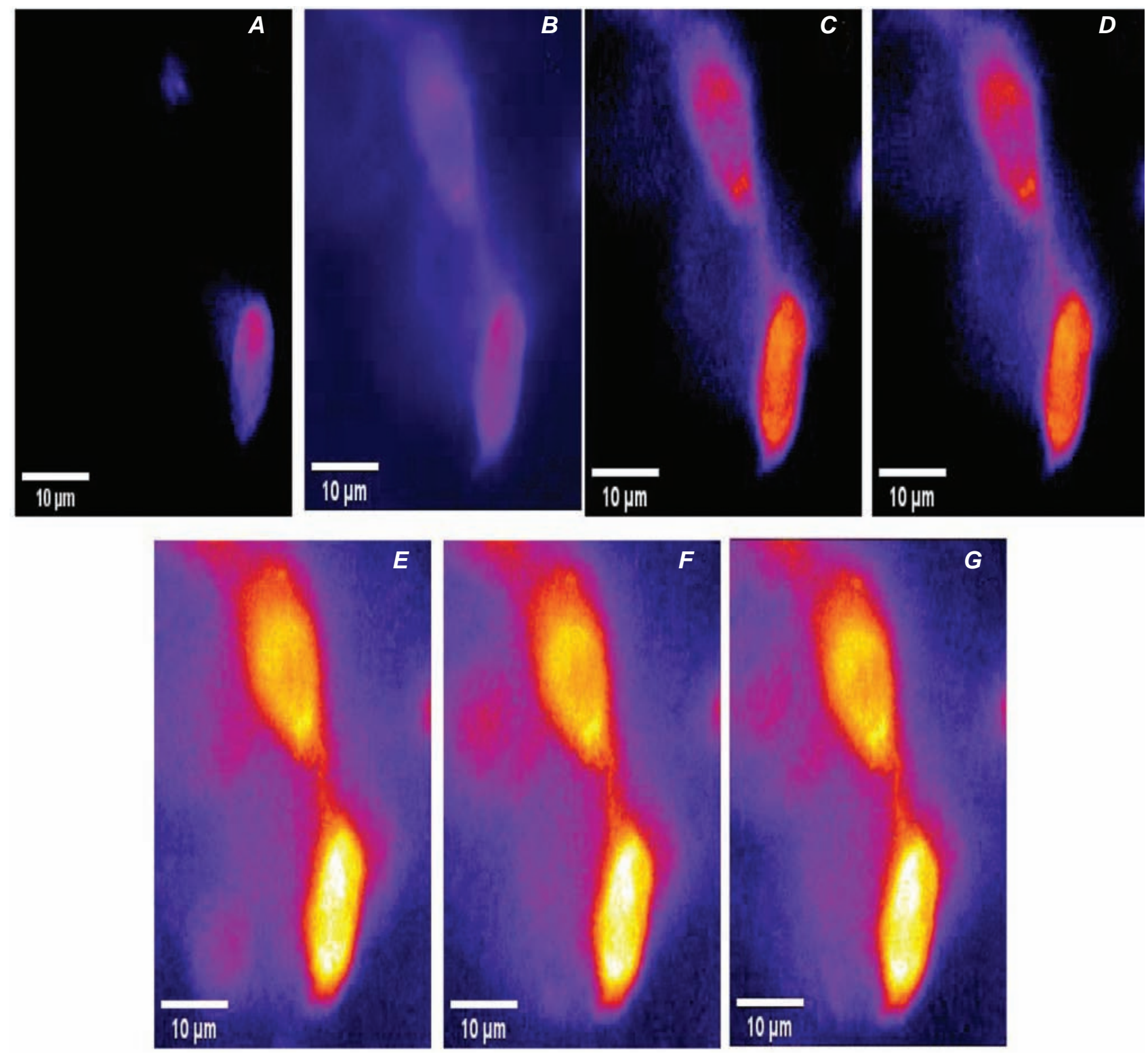

Fig. 5. Fluorescence microscopy showed an increase in thiacalix[4]arene C-800 fluorescence in rat uterine cells after incubation with $\mathrm{Zn}^{2+} . \mathbf{A}$ - control; $\boldsymbol{B}$ - thiacalix[4]arene C-800, 1 min of incubation; $\boldsymbol{C}$ - thiacalix[4]arene C-800, 3 min of incubation; $\boldsymbol{D}$ - thiacalix[4]arene C-800, 5 min of incubation; $\boldsymbol{E}$ - thiacalix[4]arene $C-800+5 \mathrm{mM} \mathrm{Zn}^{2+}, 1$ min of incubation, $\boldsymbol{F}$ - thiacalix[4]arene C-800+5 $\mathrm{mM} \mathrm{Zn}^{2+}$, $3 \mathrm{~min}$ of incuba-

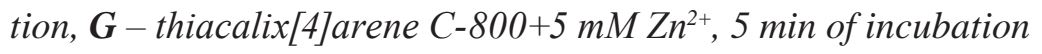

tion. This phenomenon presumably can be explained by the peculiarity of thiacalix[4]arene C-800 and $\mathrm{Zn}^{2+}$ penetration through the cell membrane and the possible interaction of thiacalix[4]arene C-800 and/ or $\mathrm{Zn}^{2+}$ with intracellular components.

The study of thiacalix[4]arene C-800 effect on the generation of reactive oxygen species (ROS) in uterine cells. The use of a fluorescent probe in living cells requires being safe for living organisms and does not cause pathological changes in the cell.
For this purpose, we studied the effect of thiacalix[4]arene C-800 on the formation of ROS in myometrial cells.

It is well-known, that ROS plays an important role in many physiological and biochemical processes [30]. However, the formation of ROS in cells under the action of toxic substances can be intensified and, thus, lead to oxidative stress, causing serious pathologies. 


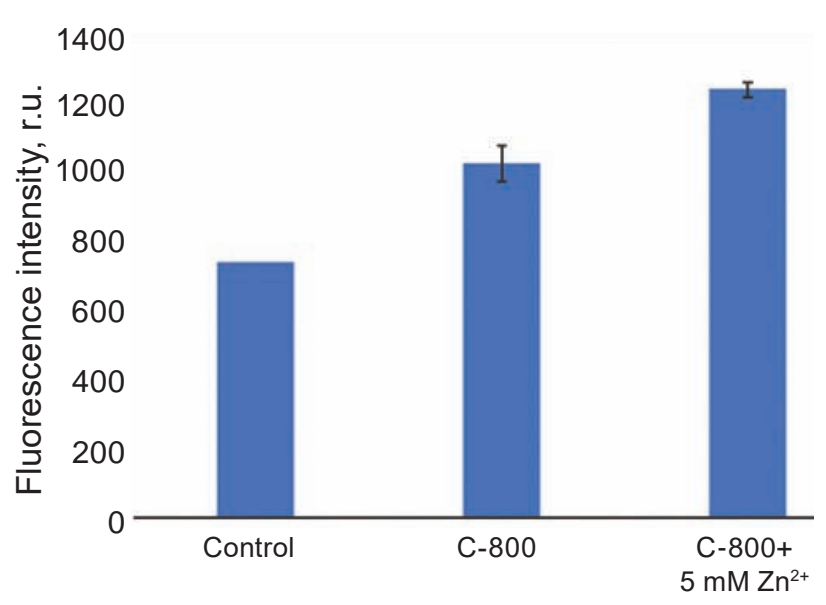

Fig. 6. Comparison of fluorescense intensity of cells incubated with C-800 and C-800 with $5 \mathrm{mM} \mathrm{ZnCl}_{2}$. Mean $\pm S D$

The production of reactive oxygen species in a suspension of rat myometrial cells under the effect of thiacalix[4]arene C-800 was studied using a sensitive probe DCF-DA (2',7'-dichlorohydrofluorescein diacetate). The DCF-DA probe can pass across the plasma membrane and penetrate cells with further deacetylation to DCFH by intracellular esterases. Non-fluorescent DCFH is oxidized with intracellular ROS to fluorescent DCF.

It was shown that the fluorescence intensity of DCF in uterine myocytes, incubated for 5 min with $100 \mu \mathrm{m}$ thiacalix[4]arene C-800, remains at the control level which could potentially indicate that production of endogenous ROS in myometrial cells does not change. The level of ROS in cells incubated under similar conditions, but with water added instead of thiacalix[4]arene C-800 solution was taken as a control (results not presented).

Conclusions. A new fluorescent probe thiacalix[4]arene C-800 for the detection of $\mathrm{Zn}^{2+}$ was characterized. The thiacalix[4]arene C-800 showed large fluorescence enhancement and high selectivity upon complexation with $\mathrm{Zn}^{2+}$, which allows the detection of $\mathrm{Zn}^{2+}$ in biological samples. The experiments on fluorescent cell imaging, MTT assay, and determination of reactive oxygen species in myometrial cells showed that the thiacalix[4]arene C-800 sensor can pass freely through a cell membrane and penetrate the cells. The conducted research has also shown, that thiacalix[4]arene C-800 is non-cytotoxic and safe for cells. Therefore, it can be used for probing $\mathrm{Zn}^{2+}$ in living cells.
Conflict of interest. Authors have completed the Unified Conflicts of Interest form at http://ukrbiochemjournal.org/wp-content/uploads/2018/12/ coi_disclosure.pdf and declare no conflict of interest.

Funding. This work was financially supported by the State Targeted Scientific and Technical Program "Nanotechnology and nanomaterials" No 0110U005970, the Targeted Comprehensive Interdisciplinary Research Program of NAS of Ukraine "Molecular and cellular biotechnology for medicine, industry and agriculture”, the Targeted Comprehensive Interdisciplinary Research Program of NAS of Ukraine "Fundamentals of molecular and cellular biotechnology” No 0110U005971, the Targeted Comprehensive Fundamental Research Program of NAS of Ukraine "Molecular design, synthesis and biological research of calix[4]arene regulators of intracellular calcium homeostasis in the smooth muscle under normal conditions and upon contractile dysfunction" No 0112 U004262.

Acknowledgements. The authors are grateful for the help with microscope setup and image acquisition to Dr. Karakhim S.O., senior researcher at the Department of Muscle Biochemistry of Palladin Institute of Biochemistry of the National Academy of Sciences of Ukraine.

\section{ТІАКАЛІКС[4]АРЕН ФОСФОНАТ С-800 ЯК НОВИЙ ФЛУОРЕСЦЕНТНИЙ ЗОНД ДЛЯ ВИЯВЛЕННЯ ІОНІВ ЦИНКУ В ЖИВИХ КЛІТИНАХ}
В. І. Яворовська ${ }^{1}$, Р. Д. Лабиниева ${ }^{1 凶}$, О. В. Бевза , А. Я. Пугач ${ }^{1}$, А. Б. Драпайло С. О. Черенок ${ }^{2}$ В. І. Кальченко ${ }^{2}$, C. O. Костерін ${ }^{1}$

${ }^{1}$ Інститут біохімії ім. О. В. Палладіна НАН України, Київ;

${ }^{2}$ Інститут органічної хімії НАН України, Київ; $\square$ e-mail: raisa.lab@gmail.com

Іони $\mathrm{Zn}$ необхідні для підтримання нормального функціонування організму людини, тому моніторинг вмісту цинку в живих клітинах та розробка сенсорних систем для його відстеження $є$ особливо важливими. Метою роботи було з'ясувати властивості синтетичного тіакалікс[4]арену С-800 (5,11,17,23-тетракіс [(гідрокси-етоксифосфоніл) метил]) - 25,26,27,28-тетрагідрокситіакалікс[4]арену) як потенційного 
флуоресцентного зонду для моніторингу $\mathrm{Zn}^{2+}$ в живих клітинах. Наші дослідження показали, що тіакалікс[4]арен C-800, який містить чотири гідрокси-етоксифосфонілметилові групи на верхньому вінці молекули, проявляв флуоресцентні властивості за $\lambda 340$ нм. Інтенсивність флуоресценції тіакалікс[4]арену С-800 істотно зростала у присутності $\mathrm{Zn}^{2+}$, тоді як $\mathrm{Mg}^{2+}, \mathrm{Ca}^{2+}, \mathrm{Cd}^{2+}$ та $\mathrm{Pb}^{2+}$, не впливали на цей показник. Комп'ютерне моделювання продемонструвало, що два катіони $\mathrm{Zn}$ взаємодіють 3 атомами кисню чотирьох гідрокси-етоксифосфонілметильних груп. Показано, що тіакалікс[4]арен С-800 швидко проникав у клітини міометрія щурів, що призводило до підвищення рівня внутрішньоклітинної флуоресценції. Додавання $\mathrm{Zn}^{2+}$ до забарвлених тіакалікс[4]ареном C-800 клітин супроводжувалося ще більшим зростанням інтенсивності внутрішньоклітинного флуоресцентного сигналу. Тіакалікс[4]арен C-800 не впливав на генерування активних форм кисню в клітинах міометрія, і не спричиняв зниження життєздатності клітин за дії у діапазоні концентрацій 50-250 мкМ. Таким чином, тіакалікс[4]арен С-800 потенційно може бути використаний як селективний флуоресцентний зонд для виявлення $\mathrm{Zn}^{2+}$ у живих клітинах.

Ключов і слова: клітини міометрія, $\mathrm{Zn}^{2+}$, тіакалікс[4]арен, молекулярна динаміка, МТТ-тест, флуоресцентний зонд.

\section{References}

1. Andreini C, Bertini I. A bioinformatics view of zinc enzymes. J Inorg Biochem. 2012; 111: 150156.

2. Andreini C, Bertini I, Rosato A. Metalloproteomes: a bioinformatic approach. Acc Chem Res. 2009; 42(10): 1471-1479.

3. Frassinetti S, Bronzetti G, Caltavuturo L, Cini M, Croce CD. The role of zinc in life: a revie. J Environ Pathol Toxicol Oncol. 2006; 25(3): 597-610.

4. Chasapis CT, Loutsidou AC, Spiliopoulou CA, Stefanidou ME. Zinc and human health: an update. Arch Toxicol. 2012; 86(4): 521-534.

5. Kumar V, Kumar A, Singh S. Zinc Deficiency and Its Effect on the Brain: An Update. Int J Mol Genet Gene Ther. 2016; 1(1): 1-7.

6. Pfaender S, Sauer AK, Hagmeyer S, Mangus K, Linta L, Liebau S, Bockmann J, Huguet G, Bourgeron T, Boeckers TM, Grabrucker AM.
Zinc deficiency and low enterocyte zinc transporter expression in human patients with autism related mutations in SHANK3. Sci Rep. 2017; 7: 45190.

7. Bao B, Prasad A, Beck FWJ, Suneja A, Sarkar F. Toxic effect of zinc on NF-kappaB, IL-2, IL-2 receptor alpha, and TNF-alpha in HUT-78 (Th(0)) cells. Toxicol Lett. 2006; 166(3): 222-228.

8. Toxicological profile for zinc. 2005. Division of Toxicology/Toxicology Information Branch 1600 Clifton Road NE Mailstop F-32 Atlanta, Georgia 30333. Regime of access : https://www. atsdr.cdc.gov/toxprofiles/tp60.pdf.

9. Lee MC, Yu WC, Shih YH, Chen CY, Guo ZH, Huang SJ, Chan JCC, Chen YR. Zinc ion rapidly induces toxic, off-pathway amyloid- $\beta$ oligomers distinct from amyloid- $\beta$ derived diffusible ligands in Alzheimer's disease. Sci Rep. 2018; 8(1): 4772.

10. Kerns K, Zigo M, Sutovsky P. Zinc: a necessary ion for mammalian sperm fertilization competency. Int J Mol Sci. 2018; 19(12): 4097.

11. Murarka S, Mishra V, Joshi P, Kumar S. Role of zinc in reproductive biology - an overview. Austin J Reprod Med Infertil. 2015; 2(2): 1009.

12. Huang Z, Lippard SJ. Illuminating mobile zinc with fluorescence from cuvettes to live cells and tissues. Methods Enzymol. 2012; 505: 445-468.

13. Nolan EM, Lippard SJ. Small-molecule fluorescent sensors for investigating zinc metalloneurochemistry. Acc Chem Res. 2009; 42(1): 193-203.

14. Ran MQ, Yuan JY, Zhao YH, Mou L, Zeng X, Redshaw C, Zhao JL, Yamato T. A multichannel thiacalix[4]arene-based fluorescent chemosensor for $\mathrm{Zn}^{2+}, \mathrm{F}^{-}$ions and imaging of living cells. Supramol Chem. 2016; 28(5-6): 418-426.

15. Wang Y, Peng X, Shi J, Tang X, Jiang J, Liu W. Highly selective fluorescent chemosensor for $\mathrm{Zn}^{2+}$ derived from inorganic-organic hybrid magnetic core/shell $\mathrm{Fe}_{3} \mathrm{O}_{4} @ \mathrm{SiO}_{2}$ nanoparticles. Nanoscale Res Lett. 2012; 7(1): 86.

16. Jiang G, Shi F, Jia Y, Cui S, Pu S. A novel donoracceptor fluorescent sensor for $\mathrm{Zn}^{2+}$ with high selectivity and its application in test paper. $J$ Fluoresc. 2020; 30(6): 1567-1574.

17. Carpenter MC, Lo MN, Palmer AE. Techniques for measuring cellular zinc. Arch Biochem Biophys. 2016; 611: 20-29.

18. Kumar R, Sharma A, Singh H, Suating P, Kim HS, Sunwoo K, Shim I, Gibb BC, Kim JS. Revisiting 
fluorescent calixarenes: from molecular sensors to smart materials. Chem Rev. 2019; 119(16): 9657-9721.

19. Morohashi N, Narumi F, Iki N, Hattori T, Miyano S. Thiacalixarenes. Chem Rev. 2006; 106(12): 5291-5316.

20. Kumar R, Lee YO, Bhalla V, Kumar M, Kim JS. Recent developments of thiacalixarene based molecular motifs. Chem Soc Rev. 2014; 43(13): 4824-4870.

21. Labyntseva R, Yavorovska V, Bevza O, Drapaylo A, Kalchenko V, Kosterin S. Thiacalix[4]arenes remove the inhibitory effects of $\mathrm{Zn}$ cations on the myosin ATPase activity. Nanoscale Res Lett. 2018; 13(1): 224.

22. Kasyan O, Swierczynski D, Drapailo A, Suwinska K, Lipkowski J, Kalchenko V. Upper rim substituted thiacalix[4]arenes. Tetrahedron Lett. 2003; 44(38): 7167-7170.

23. Kharchenko SG, Drapailo AB, Kalchenko OI, Yampolska GD, Shishkina SV, Shishkin OV, Kalchenko V I. Thia- and sulfonyl-calix[4]arene methylphosphonous acids: synthesis, structure, and amino acids binding. Phosphorus, Sulfur Silicon Related Elements. 2013; 188(1-3): 243248.

24. Gangula PR, Dong YL, Yallampalli C. Rat myometrial smooth muscle cells express endothelial nitric oxide synthase. Hum Reprod. 1997; 12(3): 561-568.

25. Vadivelu RK, Yeap SK, Ali AM, Hamid M, Alitheen NB. Betulinic Acid inhibits growth of cultured vascular smooth muscle cells in vitro by inducing $\mathrm{G}_{1}$ arrest and apoptosis. Evid Based Complement Alternat Med. 2012; 2012: 251362.

26. Schindelin J, Arganda-Carreras I, Frise E, Kaynig V, Longair M, Pietzsch T, Preibisch S, Rueden C, Saalfeld S, Schmid B, Tinevez JY, White DJ, Hartenstein V, Eliceiri K, Tomancak P, Cardona A. Fiji: an open-source platform for biological-image analysis. Nat Methods. 2012; 9(7): 676-682.

27. Regime of access: http://www.hypercubeusa. com/Default.aspx?tabid=363

28. Kimura E, Koike T. Recent development of zincfluorophores. Chem Soc Rev. 1998; 27(3): 179184.

29. Bugaenko LT, Ryabykh SM, Bugaenko AL. A nearly complete system of average crystallographic ionic radii and its use for determining ionization potentials. Moscow Univer Chem Bull. 2008; 63(6): 303-317.

30. Zhao RZ, Jiang S, Zhang L, Yu ZB. Mitochondrial electron transport chain, ROS generation and uncoupling (Review). Int $\mathrm{J} \mathrm{Mol} \mathrm{Med.} \mathrm{2019;}$ 44(1): 3-15. 